\title{
Philanthropic Commitment Traits for Waqf in Higher Education
}

\author{
Siti Khadijah, A. M. (Corresponding Author) \\ Academy of Contemporary Islamic Studies (ACIS), \\ Universiti Teknologi MARA Selangor, 40450 Shah Alam Selangor, Malaysia \\ Tel: +6019-2852275 E-mail: ctkhadijah48@gmail.com \\ Muhammad Sabki, S. \\ Arshad Ayub Graduate Business School, AAGBS UiTM, \\ 40450 Shah Alam, Selangor, Malaysia \\ Tel: +6 017-3305540 E-mail: muhdsabki@yahoo.com \\ Ismail, A. \\ Arshad Ayub Graduate Business School, AAGBS UiTM, \\ 40450 Shah Alam, Selangor, Malaysia. \\ Tel: +6019-3817315 E-mail:drismailphd990@gmail.com
}

\begin{abstract}
Philanthropic commitment in the form of waqf is important particularly among younger working adults in ensuring sustainable flow of funds for charitable purposes. One of the vital usages of such funds is funding for higher education. A question is raised on the commitment of younger adults in such giving. This study examines waqf commitment traits among waqif (waqf contributors) for higher education funding. The specific objective of this study is to measure the factors that influence the waqif to contribute their property or income into waqf for higher education fund. For the purpose of this study, 400 questionnaires have been distributed to working young adult respondents in the Klang Valley area. Waqf commitment attributes comprising of Religiosity, Trust, Altruism, Personal Characteristics, SelfImage, Psychological Benefits, Social Norms and Personal Satisfaction are examined. The findings reveal that Religiosity, Altruism, Personal Satisfaction and Commitment are significant attributes in explaining waqf commitment. However, Trust and Social Norm are not significant.
\end{abstract}

Keywords: Commitment attributes; Charity; Philanthropy; Waqf; Waqif

\section{Introduction}

Islam is a complete and comprehensive deen (way of life) that has an in-built distributive mechanism in the form of philanthropic contribution like zakat and waqf. In fact, the act of giving away one's wealth for charitable purposes is a pious and religiously motivated spending of a Muslim. Waqf indeed, has a significant role in the development of Islamic economic principles with reference to the wealth redistribution and elimination of poverty in the society (Amirul Faiz, Sheila \& Mustafa, 2012).

The term waqf originates from the Arabic word of waqafa, which means to hold or retain. In Islamic Law, the word waqf is defined as holding of a property and preserving it so that its fruit, revenue or usufruct could be used for the benefit of its beneficiaries. Waqf can be juristically defined as putting a hold on a property and keeping it for the state (Ibrahim, 2008). The benefit will be used exclusively for its objective of righteousness while prohibiting any other use or disposition of it outside its specified objectives (Kahf, 1998).

The study of waqf has caught the attention of many researchers today, a phenomenon that may be attributed to the increase in the awareness of Muslims on the significance of having waqf 
in the society. In the past, studies have shown that waqf was merely individual donations to be used by the public with the objectives of improving their lives (Eikenberry, 2005). As waqf is philanthropic in nature, a person cannot be accused of being irresponsible if he opted not to contribute to waqf.

Perhaps, one of the main motivating factors that drive a person to contribute to waqf is the everlasting rewards promised to the contributor (waqif). In the Qur'an, God says, "They ask you (O Muhammad) what they should spend in charity. Say: 'Whatever you spend with a good heart, give it to parents, relatives, orphans, the helpless, and travellers in need. Whatever good you do, God is aware of it." (Al-Quran, 2: 215). The verse clearly states that helping other Muslims would obtain reward from God in this world and also in the Hereafter. The reward is mentioned clearly in the Qur'an in Surah al-Baqarah verse 261, "The example of those who spend their wealth in the way of Allah is like a seed [of grain] which grows seven spikes; in each spike is a hundred grains. And Allah multiplies [His reward] for whom He wills. And Allah is all-Encompassing and Knowing”.

In the same regard, a hadith of the Prophet mentions that: "When a human being dies, his good works come to an end except for three: a lasting charity, knowledge that benefits others, and his good child who continuously prays for his blessings, "(Muslim). In this sense, waqf comes as a form of continuous and perpetual charity or sadaqah jariah where the rewards from Allah S.W.T for the waqif will continue even after his death and for as long as the waqf asset could provide benefit for its consumer or beneficiaries.

As waqf contribution is voluntary in nature, a specific study on the attributes of waqf commitment is essential in order to examine the factors contributing to the generous attitude of the public. This is particularly essential owing to the importance of waqf as a sustainable tool for the socio-economic development of the Muslim community.

\section{Literature Review}

Waqf has been discussed extensively in many studies due to the increased awareness of Muslims on the importance of having the tool in the society. Waqf is a form of voluntary giving where the material benefit would not only return to the giver, but also and specifically to be enjoyed by the public as a whole. In Malaysia, waqf property is managed by the State Islamic Religious Council whereby any realized benefit would then be extended to the beneficiaries (Azman, Mohammad, \& Syed Mohd Najib, 2012; Ahmad Faizul et al., 2015). Among the important benefits of waqf is its use in funding for higher education.

As giving waqf is voluntary in nature, previous studies have identified many motivating traits or factors of voluntary charitable giving. Among the identified factors of donating money and doing charity is religion. One particular study, for example, found that religiosity plays an important role in motivating young adults to contribute to charity (Opoku, 2013). Catherine and Grossman (2004) explain the religiosity concept by stating that spiritual value will place a greater emphasis on the spiritual rather than material matters. Apart from religion, Martin (1994) argues that the motivation for helping others may come from either egoism or altruism, or both. By enhancing the welfare of the needy, it will be an ultimate goal for altruistic motivation, even at the expense of a person's own interest.

When engaging in volunteering activities, a person will inevitably increase his life satisfaction as it reflects from brain to notion analysis. Charity work is a form of volunteering deed which gives life and personal satisfaction to the individuals involved. Consistent with other correlational studies of volunteering and well-being, it has been found that higher levels of volunteer work are associated with higher levels of overall life satisfaction. Research 
indicates that personal satisfaction gain is intrinsic to the donating behaviour, whereas extrinsically, donation enhances one's social standing (Mayo \& Tinsley, 2009).

Trust is another important factor in charity. Trustworthiness can be acquired through various ways, including establishing the organization through the government as a registered charity, securing board members whose reputations might indicate trust, and seeking relationships and associations with other trusted organizations (Handy, 2000). In gaining donors' trust, an organization has to maintain confidence in each donor's future behaviour with them through cultivated good relationships. Hence, trust and satisfaction has been the strongest predictors of donors influencing their involvement with charitable organization (Water, 2010).

Personal character may reflect individual behaviour. Moral norms are the main driver behind donation intentions, where personal or moral norms are broadly defined as an individual's internalized code of conduct. Stern et al. (1999) propose that feelings of personal obligation and moral responsibility lead to the formation of pro-social behaviour that includes charitable giving. Social norms will give an impact by telling a donor of contributions made by another person influencing their belief about the descriptive norm, which in turn influences their giving behaviour (Croson, Handy \& Shang, 2009). The findings suggest that social norms influence donating intentions due to an individual's identity as it relates to their own personal community.

Psychological benefit has little effect if potential donors face psychological costs when confronted with the need. In an early study, a picture of a needy, handicapped child was found to depress giving in a door-to-door fundraising campaign presumably because it depressed the mood of potential donors (Isen \& Noonberg, 1979).

Another factor that would drive a person to give is commitment. Commitment is defined as an enduring desire or intention to develop and maintain a stable relationship (Sargeant $\&$ Woodliffe, 2007). In line with the context of this study, it can be considered as a form of psychological attachment to the charitable organization.

One other factor is the concern with self-image, a concern that could promote pro-social behaviour because observing or remembering their good actions reassures people that they are indeed pro-social. Dana, Weber and Kuang (2007) demonstrate that individuals behave more selfishly in situations in which it is possible to dilute self-signals of altruism. On the contrary, research done by Weele and Siemens (2014) found that self-image concerns have no effect on charitable giving.

\section{Methodology}

This study is quantitative in nature. The primary data are obtained from the structured questionnaires to examine the waqf commitment attributes of the public. The collected data were analysed using reliability test, descriptive analysis t-test and multiple regressions. A total of 400 questionnaires were distributed to adult Muslims working in Malaysia's Klang Valley area. The respondents were aged between 20 to 60 years old with experience and knowledge on waqf. Multiple regression was used to determine the relationship between the attributes of waqf commitment and waqf contribution. Apart from demographic profile, the descriptive statistics and the validity test are being analysed. Nine independent variables comprising of religiosity, altruism, personal satisfaction, trust, personal character, social norm, psychological benefits, commitment and self-image were commitment attributes analysed in this study. All the variables are measured using Lickert Scale of $1=$ totally disagree, to $6=$ totally agree.

Reliability test is conducted to check the reliability of the instrument. Reliability test is important to ensure that there exists internal consistency of the measures, thereby the 
"items hang together as a set and be capable of independently measuring the same concept" (Sekaran, 2003). In this study, the Cronbach's Alpha for every element is greater than 0.6.

Table 1: Reliability Test of Determinant of Waqf Commitment

\begin{tabular}{|l|l|l|}
\hline Dimension & No. of Item & Cronbach's Alpha \\
\hline Trust & 3 & 0.744 \\
\hline Altruism & 3 & 0.901 \\
\hline $\begin{array}{l}\text { Personal } \\
\text { Characteristics }\end{array}$ & 3 & 0.784 \\
\hline Self-Image & 3 & 0.721 \\
\hline Religiosity & 3 & 0.705 \\
\hline $\begin{array}{l}\text { Psychological } \\
\text { Benefits }\end{array}$ & 3 & 0.725 \\
\hline Social Norms & 3 & 0.885 \\
\hline $\begin{array}{l}\text { Personal } \\
\text { Satisfaction }\end{array}$ & 3 & 0.881 \\
\hline Commitment & 2 & 0.752 \\
\hline Waqf Contribution & 9 & 0.861 \\
\hline
\end{tabular}

The reliability outcome that is above 0.8 is considered good, 0.7 is considered acceptable, while a value less than 0.6 is considered poor (Sekaran, 2003). As shown in Table 2, all the variables in this study have Cronbach alpha values of more than 0.7 . We can thus conclude that the internal consistency of each variable is considered good. The instrument is therefore reliable for the study.

\section{Results \& Discussion}

The demographic profile of the respondents is shown in Table 2. More than half of the respondents $(66 \%)$ are female. This might indicate the fact that a significant number of females is at the workplace apart from them having a more approachable attitude. The majority of them (85.8\%) are aged 21 to 40 years old and of course this is important as the main target of the study is younger adults.

Many of them possessed an academic degree $(73.5 \%)$ or even higher education, and only a handful of them had lower education background. This indicates that they are mainly educated as they managed to pursue their study at a higher level. Many of the respondents (64\%) work at private sectors, quite a number of them are civil servants $(22.8 \%)$ and few (6.8\%) are selfemployed. There are also those who commit themselves to doing voluntary works at Nongovernment Organization or NGO (6.5\%).

Table 2: Demographic Profile $(n=400)$.

\begin{tabular}{|c|c|c|c|c|c|}
\hline Profiles & Frequency & Percentage $(\%)$ & Profiles & Frequency & Percentage $(\%)$ \\
\hline $\begin{array}{l}\text { Gender } \\
\text { Male } \\
\text { Female }\end{array}$ & $\begin{array}{l}136 \\
264\end{array}$ & $\begin{array}{l}34 \\
66\end{array}$ & $\begin{array}{l}\text { Profession } \\
\text { Public } \\
\text { Private } \\
\text { Self-employed } \\
\text { NGO } \\
\text { Others }\end{array}$ & $\begin{array}{l}91 \\
256 \\
27 \\
26 \\
23\end{array}$ & $\begin{array}{l}22.8 \\
64 \\
6.8 \\
6.5 \\
6.6\end{array}$ \\
\hline Total & 400 & 100 & Total & 400 & 100 \\
\hline $\begin{array}{c}\text { Age } \\
21-30 \\
31-40 \\
41-50 \\
51-60\end{array}$ & $\begin{array}{c}284 \\
59 \\
32 \\
25\end{array}$ & $\begin{array}{c}71 \\
14.8 \\
8 \\
6.3\end{array}$ & $\begin{array}{c}\text { Marital Status } \\
\text { Single } \\
\text { Married }\end{array}$ & $\begin{array}{l}263 \\
137\end{array}$ & $\begin{array}{l}65.8 \\
34.3\end{array}$ \\
\hline Total & 400 & 100 & Total & 400 & 100 \\
\hline $\begin{array}{c}\text { Education } \\
\text { Secondary School } \\
\text { Certificate } \\
\text { Diploma } \\
\text { Degree } \\
\text { Masters } \\
\text { PhD }\end{array}$ & $\begin{array}{c}9 \\
\\
20 \\
43 \\
294 \\
28 \\
6\end{array}$ & $\begin{array}{c}2.3 \\
\\
5 \\
10.8 \\
73.5 \\
7 \\
1.5\end{array}$ & & & \\
\hline Total & 400 & 100 & & & \\
\hline
\end{tabular}


As far as marital status is concerned, it is not surprising that the number of unmarried respondents (263 or $65.8 \%$ ) surpassed the number of those who are already married (137 or $34.3 \%$ ) as the majority of the respondents are still young.

Table 3: Descriptive analysis for waqf commitment variable

\begin{tabular}{|c|c|c|}
\hline & Mean & Std. Deviation \\
\hline Trust & 3.94 & 1.039 \\
\hline Altruism & 5.13 & 0.804 \\
\hline Personal character & 3.44 & 1.297 \\
\hline Self-image & 2.1 & 1.066 \\
\hline Religiosity & 4.98 & 0.933 \\
\hline $\begin{array}{c}\text { Psychological } \\
\text { benefits }\end{array}$ & 4.2 & 1.133 \\
\hline Social norm & 4.1 & 1.324 \\
\hline $\begin{array}{c}\text { Personal } \\
\text { satisfaction }\end{array}$ & 4.95 & 0.915 \\
\hline Commitment & 3.24 & 1.103 \\
\hline $\begin{array}{c}\text { Contribution } \\
\text { commitment }\end{array}$ & 4.55 & 0.859 \\
\hline
\end{tabular}

As for Table 3, the Descriptive Statistics show that altruism is the most that the donors considered as the dimension to measure their waqf contribution. It has the highest mean of

5.13 with low standard deviation 0.804 , which is good. Religiosity is considered as the second trait to indicate waqf contribution, with its mean value of 4.98 and its standard deviation of 0.93 . These two traits are indeed reflecting a religiously-driven trait of the respondents in giving for charity. They placed personallydriven traits as secondary as the mean for personal satisfaction is lower (mean value of 4.95 and its standard deviation of 0.915 ). The same goes to Psychological benefit (a mean value of 4.2 and standard deviation of 1.13). Social norm mean value is slightly above 4 and the other elements are less than 4. Self-image is found to have the lowest mean among the traits $($ mean $=2.1$; standard deviation $=1.066)$. This may imply the sincerity and honesty of the respondents in giving for charity as the main aim is to seek the pleasure of the Almighty, and not for boosting one's self-image.

\section{Multiple Regression Output}

The multiple regression output is shown in Table 4. The output is important to look at the significance of the relationship between independent and dependent variables, thereby determining the significant traits of philanthropic commitment. The output shows that the value of adjusted R-square is 0.594 . It indicates that the independent variables are able to explain $59.40 \%$ of the dependent variable. The $\mathrm{F}$ test indicates that the model is significant at 1 percent.

Findings of this study indicate that Altruism, Religiosity, Personal satisfaction and Commitment are significant at 1\%. Meanwhile, Psychological Benefits and Personal Characteristic are significant at 10\%. However, Trust and Social Norm are not significant.

Religiosity has the highest coefficient value. Every increase of $1 \%$ in religiosity increases waqf contribution up to $29.5 \%$. Next is Altruism, where a $1 \%$ increases in its value increases the waqf contribution by $18.5 \%$.

Table 4: Multiple Regression Result

\begin{tabular}{|c|c|c|c|l|l|l|l|l|l|}
\hline Variable & Trust & Altruism & Personal & Self-image & Religiosity & Psychology & $\begin{array}{c}\text { Social- } \\
\text { norm }\end{array}$ & $\begin{array}{l}\text { Satisfaction } \\
\text { Commitment }\end{array}$ \\
\hline $\begin{array}{c}\text { Co- } \\
\text { Efficient } \\
\text { (P-Value) }\end{array}$ & $\begin{array}{c}0.020 \\
(0.581)\end{array}$ & $\begin{array}{l}0.185 \\
(0.000) * * *\end{array}$ & $\begin{array}{c}0.068 \\
(0.090) *\end{array}$ & $\begin{array}{l}0.051 \\
(0.205)\end{array}$ & $\begin{array}{l}0.295 \\
(0.000)^{* * *}\end{array}$ & $\begin{array}{l}0.077 \\
(0.066)^{*}\end{array}$ & $\begin{array}{l}0.017 \\
(0.672)^{* * *}\end{array}$ & $\begin{array}{l}0.267 \\
(0.000) * * *\end{array}$ & $\begin{array}{l}0.175 \\
(0.000) * * *\end{array}$ \\
\hline
\end{tabular}


Similarly, an increase of $1 \%$ in personal satisfaction increases the waqf contribution by $26.7 \%$. The last variable that has positive relationship with waqf contribution, which is commitment, indicates that $1 \%$ of its increase potentially increases the waqf contribution by 17.5\%. Psychological Benefits and Personal Characteristic have negligible effect.

This study finds that religiosity has positive effect on cash waqf giving, which means that it has the intrinsic motivation to the waqif. After all, Islam views religion as consisting of the triple mandate of faith (iman), action ( $\mathrm{amal}$ ), and worship (ibadah). The findings of this study confirm previous studies that religion is the key element that will lead to a positive impact on contribution (Mokhlis, 2009; Amin et al., 2014). As waqf contribution is commendable by God, it is no surprise that this study finds religiosity a significant factor for waqf contribution among working adult.

\section{Conclusion and Recommendation}

Nine independent variables have been tested for this study to identify the factors that motivate waqif to contribute for waqf. They are Trust, Altruism, Personal Characteristics, Self-Image, Religiosity, Psychological Benefits, Social Norms, Personal Satisfaction and Commitment. The dependent variable is Waqf Contribution. This study found that only four attributes were significant to waqf commitment, and they are, Religiosity, Altruism, Personal Satisfaction and Commitment. The four attributes are, to our best judgment, symbols of piousness of the waqif. These attributes nevertheless, could not be quantified and measured to identify one's commitment. Perhaps, it would be very useful for future researchers on waqf to measure the waqf index for the determinants of waqf commitment among Muslims or waqif. In addition, as waqf is one of the tools for distributive justice as it provides socio-economic stability, a study on its role in achieving the Maqasid Shariah (the objectives of shariah) is recommendable in order to empirically demonstrate its importance.

\section{Acknowledgement}

The researchers would like to give a special gratitude to Universiti Teknologi Mara and the Ministry of Higher Education for funding this research under Long-Run Research Grant (LRGS).

\section{References}

Ahmad, F. S., Jamil, H., Wan Sabri, W. Y., Anas, Y., Saadiah, M., Afrah Munirah, Y., Nur Hidayah, Z., Hanita, H., \& Izham Zainal, A. (2015). A Conceptual Model for Inter-State Corporate Waqf Financing for Higher Learning. Global Journal Al-Thaqafah. 5 (1), 51-58

Amirul Faiz, O., Sheila, N. N. H., \& Mustafa Omar, M. (2012). Determinants of cash waqf giving in Malaysia: Survey of selected works. In In: Workshop Antarbangsa Pembangunan Berteraskan Islam V (WAPI-5), 10 Apr 2012, Medan, Indonesia, 186-243, 2012. Retrieved from http://irep.iium.edu.my/28284/.

Azman, A. R., Mohammad, A., \& Syed Mohd Najib, S. O. (2012). Zakat Institution in Malaysia: Problems and Issues. Global Journal Al-Thaqafah. 2 (1), 35-41

Catherine, C. E., \& Philip, J. G. (2004). Giving to Secular Causes by the Religious and Nonreligious: An Experimental Test of the Responsiveness of Giving to Subsidies. Non-profit and Voluntary Sector Quarterly. 33 (2), 271-289

Croson, R., Handy, F., \& Shang, J. (2009). Keeping Up with the Joneses: The Relationship between Norms, Social Information and Subsequent Charitable Giving, Nonprofit Management and Leadership. 19 (Summer): 467-489.

Dana, J., Roberto, A. Weber, J., \& X. K. (2007). Exploiting moral wiggle room: experiments demonstrating an illusory preference for fairness. Economic Theory. 33, 67-80 
Eikenberry, A. M. (2005). Fundraising or promoting philanthropy? A qualitative study of the Massachusetts Catalogue for Philanthropy. Int. J. Nonprofit Volunt. Sect. Mark. 10, 137-149

Handy, F. (2000). How we beg: The analysis of direct mail appeals. Nonprofit and Voluntary Sector Quarterly, 29 (3), 439-454

Ibrahim, M. B. (2008). Pelaksanaan Skim Wakaf Tunai oleh Yayasan Waqaf Malaysia, Jurnal Pengurusan Jawhar, Vol. 2, No. 1.

Isen Alice, M., \& Noonberg, A. (1979). The Effect of Photographs of the Handicapped on Donation to Charity: When a Thousand Words May be too Much. Journal of Applied Social Psychology. 9 (5), 426-431

Kahf, M. (1998) Financing the Development of Awqaf Property, Paper presented at the Seminar on Development of Awqaf organized by Islamic Research and Training Institute (IRTI), Kuala Lumpur.

Mayo, J. W., \& Tinsley, C. H. (2006). Warm glow and charitable giving: Why the wealthy do not give more to charity? Journal of Economic Psychology. 30 (3), 490-499

Martin, M. W. (1994). Virtuous Giving: Philanthropy, Voluntary Service, and Caring. USA: Indiana University Press.

Opoku, R. A. (2013). Examining the motivational factors behind charitable giving among young people in a prominent Islamic country, International Journal of Non-profit and Voluntary Sector Marketing. 18, 172-186

Sargeant A., \& Woodliffe, L.(2007) Building Donor Loyalty: The Antecedents and Role of Commitment in the Context of Charity Giving. Journal of Non-profit \& Public Sector Marketing, 18(2), 1-33.

Sekaran, U. (2003). Research method for business: A skill building approach. USA: John Wiley and Sons, Inc.

Stern P. C., Dietz T., Abel T., Guagnano G.A., \& Kalof, L. (1999). A value-belief-norm theory of support for social movements: The case of environmentalism. Human Ecology Review, $6,81-97$.

Water, R. D. (2010). Increasing Fundraising Efficiency through Evaluation: Applying Communication Theory to the Non-profit Organization-Donor Relationship. Non-profit and Voluntary Sector Quarterly XX(X) 1-18

Weele, V. D., Joël, J., \& Von, S. F. (2014). Bracelets of Pride and Guilt? An Experimental Test of Self-Signaling in Charitable Giving CESifo Working Paper, No. 4674 